\title{
Antibiotic resistance phenotypes of Salmonella isolates of broiler meat and chicken origin
}

\author{
Seran TEMELLI ${ }^{1}$, Serpil KAHYA ${ }^{2}$, Aysegul EYIGOR ${ }^{1}$, Kamil Tayfun CARLI $^{2}$ \\ ${ }^{1}$ Department of Food Hygiene and Technology, and ${ }^{2}$ Department of Microbiology, Uludag University, Faculty of Veterinary \\ Medicine, Bursa, Turkey.
}

Summary: This study aims to determine the antibiotic resistance phenotypes of Salmonella isolates of broiler meat and chicken samples against a total of 23 antimicrobial agents. For this, 64 meat and 79 chicken Salmonella isolates, which were obtained from retail meat and farm samples analyzed in our laboratory from February 2006 to January 2009, were used. All Salmonella isolates were resistant to at least 4 antimicrobials tested, with the common highest resistance rates to erythromycin (100.0\%), bacitracin (99.3\%), and rifampicin (98.6\%), regardless of the sample type. Additionally, meat isolates were $100.0 \%$ resistant to bacitracin, clindamycin, erythromycin, rifampicin, and chicken isolates were $100.0 \%$ resistant to erythromycin, spiramycin, penicillin G, doxycycline hydrochloride, and tetracycline. Four to 7 Multi Drug Resistant (MDR) Salmonella conformed $82.83 \%$ of all meat isolates, and 10, 12, 15, and 17 MDR Salmonella conformed $55.68 \%$ of all chicken isolates analyzed. The B/DA/E/RD and $\mathrm{N} / \mathrm{B} / \mathrm{CT} / \mathrm{E} / \mathrm{SP} / \mathrm{P} / \mathrm{RD} / \mathrm{DO} / \mathrm{OT} / \mathrm{TE}$ resistances were the most common patterns as $35.94 \%$ and $13.92 \%$ within meat and chicken isolates, respectively. The considerably high resistance rates and MDR types to commonly used antimicrobial agents among the Salmonella isolates tested pose a significant risk factor for the treatment of foodborne Salmonella infections in humans.

Keywords: Salmonella, chicken, broiler meat, antimicrobial resistance.

\section{Tavuk eti ve tavuk orijinli Salmonella izolatlarında antibiyotik dirençlilik fenotipleri}

Özet: Bu çalışmada tavuk eti ve tavuk orijinli Salmonella izolatlarında 23 antimikrobiyal ajana karşı dirençlilik fenotiplerinin belirlenmesi amacı ile perakende satış yerleri ve çiftlik örneklerinden elde edilen 64 adet et ve 79 adet tavuk Salmonella izolatı, Şubat 2006 ile Ocak 2009 arasında laboratuvarımızda analiz edildi. Tüm Salmonella izolatlarının, örnek tipi göz önünde bulundurulmaksızın, test edilen antimikrobiyalleden en yüksek direnç oranı ile sırası ile eritromisin'e (\%100.0), basitrasin'e (\%99.3) ve rifampisin'e (\%98.6) olmak üzere en az 4 antimikrobiyale dirençli olduğu belirlendi. Ayrıca, et izolatlarının basitrasin, klindamisin, eritromisin, rifampisin'e; tavuk izolatlarının ise eritromisin, spiramisin, penisilin G, doksisiklin hidroklorür ve tetrasiklin'e \%100.0 dirençli olduğu bulundu. Tüm et izolatlarının \%82.83’ü 4 ile 7 Çoklu İlaç Direnci (ÇİD) gösterirken, tüm tavuk izolatlarının \%55.68'i 10, 12, 15 ve 17 antimikrobiyale ÇİD gösterdiği belirlendi. Et izolatlarında \%35.94 oranında ve tavuk izolatlarında ise \%13.92 oranında olmak üzere en sı rastlanan Çİ paternleri sırasıyla B/DA/E/RD ve N/B/CT/E/SP/P/RD/DO/OT/TE olarak bulundu. Salmonella izolatlarında karşılaşılan bu yüksek dirençlilik oranlarının ve ÇiD paternlerinin insanlardaki Salmonella infeksiyonlarının tedavisinde risk oluşturabileceği belirtildi.

Anahtar sözcükler: Salmonella, tavuk, broyler eti, antimikrobiyal direnç

\section{Introduction}

Salmonella enterica serovars, the etiological agents of foodborne salmonellosis worldwide, are carried by chicken and transmitted to humans mainly by contaminated broiler meat (19). Treatment of these types of infections becomes limited as a consequence of the rising antimicrobial resistance, which appears to be a direct result of acquiring these increasingly resistant strains from farm animals, particularly by the consumption of chicken meat acquiring Salmonella (9). Strategies applied in antimicrobial use both for treatment and for prophylactic/growth promoting purposes in chicken production had significant roles in the emergence, persistence and spread of these antimicrobial resistant strains in the food chain.

In recent years, there are several reports on Salmonella isolates that are resistant to several antimicrobial agents (Multi Drug Resistant - MDR) both in the developed and developing countries from chicken meat $(4,15,17,18,21,22,23)$, and from chickens $(3,5$, $7,10,12)$. The emergence of these MDR Salmonella has significant outcomes for the safety of the food supply, namely chicken meat, directly as a source of MDR Salmonella, and indirectly as a reservoir of antimicrobial genetic elements that can be exchanged between intestinal bacteria (2). Also as the human exposure to 
these MDR Salmonella via the food supply increases, infections can frequently become harder to treat (2). In our country, up to our knowledge, there are only a few studies indicating the presence of antibiotic resistance in Salmonella isolated from chicken meat (13) and from chickens $(11,14)$, showing requirement of more data by further studies.

In this study, antibiotic resistance phenotypes of 143 Salmonella isolates of broiler meat and chicken origin were determined against a total of 23 antimicrobials, which are widely used in veterinary and human medicine.

\section{Materials and Methods}

Salmonella isolates: Sixty four retail broiler meat, and 79 chicken farm samples (41 cloacal swab, 7 intestine, 22 caecum and 9 gizzard), which were determined as positive for Salmonella in our laboratory from February 2006 to January 2009 were the sources of these isolates. Isolates obtained from these sources had been subjected to both biochemical identification by API 20E (Biomerieux, 20100, France), and serological identification using Salmonella group-specific antisera (Becton-Dickinson, USA).

Antimicrobial susceptibility test: Antimicrobial profile of each Salmonella isolate was determined by the disk agar diffusion method according to the guidelines of the Clinical and Laboratory Standards Institute (6) as follows: A loopful of the Salmonella stock culture was streaked onto 7\% sterile sheep blood added Blood Agar Base No:2 plate (Oxoid, CM0271) and incubated at $37^{\circ} \mathrm{C}$ for $24 \mathrm{~h}$. One colony per plate was transferred into $5 \mathrm{ml}$ of Tryptone Soya Broth (Oxoid, CM0129) and was incubated at $37^{\circ} \mathrm{C}$ for $6 \mathrm{~h}$. After turbidity adjustment to $0.5 \mathrm{McFarland}$ by dilution, a sterile swab was dipped into the inoculum and streaked onto Mueller-Hinton Agar (Oxoid, CM0337) plate three times, where the plate was turned $120^{\circ}$ each time. Plates were allowed to dry keeping the lid slightly apart for $1 \mathrm{~h}$. The commercial antibiotic discs were placed in such a way that their centers were at least $30 \mathrm{~mm}$ apart and at least $10 \mathrm{~mm}$ away from the edge of the plate. Plates were incubated at $37^{\circ} \mathrm{C}$ and examined at 18 and $24 \mathrm{~h}$. Zone diameters of complete inhibition were measured and the interpretation was done following the recommendation of the disc manufacturer. The 23 antimicrobial agents tested and their corresponding concentrations were as follows: Amikacin (AK, $30 \mu \mathrm{g}$, Oxoid CT0107B), Amoxycillin/ Clavulanic acid (AMC, $30 \mu \mathrm{g}$, Oxoid CT0223B), Ampicillin (AMP, $10 \mu \mathrm{g}$, Oxoid CT0003B), Apramycin (APR, 15 $\mu \mathrm{g}$, Oxoid CT0545B), Bacitracin (B, 10 units, Oxoid CT0005B), Ceftiofur (EFT, $30 \mu \mathrm{g}$, Oxoid CT1751B), Cephalexin (CL, $30 \mu \mathrm{g}$, Oxoid CT0007B),
Cephazolin (KZ, $30 \mu \mathrm{g}$, Oxoid CT0011B), Ciprofloxacin (CIP, $1 \mu \mathrm{g}$, Oxoid CT0623B), Clindamycin (DA, $10 \mu \mathrm{g}$, Oxoid CT0015B), Colistin sulphate (CT, $10 \mu \mathrm{g}$, Oxoid CT0017B), Doxycycline hydrochloride (DO, $30 \mu \mathrm{g}$, Oxoid CT0018B), Enrofloxacin (ENR, $5 \mu \mathrm{g}$, Oxoid CT0639B), Erythromycin (E, $15 \mu \mathrm{g}$, Oxoid CT0020B), Gentamicin (CN, $120 \mu \mathrm{g}$, Oxoid CT0794B), Neomycin (N, $30 \mu \mathrm{g}$, Oxoid CT0033B), Oxytetracycline (OT, $30 \mu \mathrm{g}$, Oxoid CT0041B), Penicillin G (P, 10 units, Oxoid CT0043B), Rifampicin (RD, $5 \mu \mathrm{g}$, Oxoid CT0207B), Spiramycin (SP, $100 \mu \mathrm{g}$, Oxoid CT0232B), Streptomycin (S, $10 \mu \mathrm{g}$, Oxoid CT0047B), Sulphamethoxazole/Trimethoprim 19:1 (SXT, $25 \mu \mathrm{g}$, Oxoid CT0052B), Tetracycline (TE, $10 \mu \mathrm{g}$, Oxoid CT0053B). The reference bacterial strains E. coli (ATCC 25922) and S. aureus (ATCC 25923) were used as quality control strains following the recommendations of CLSI (6).

\section{Results}

All broiler meat isolates were found 100.0\% resistant to bacitracin, clindamycin, erythromycin and rifampicin, regardless of the serogroups tested. All serogroup based antimicrobial resistance rates are summarized in Table 1. Chicken isolates, which all belonged to serogroup $\mathrm{D}$, were found $100.0 \%$ resistant to erythromycin, spiramycin, penicillin $\mathrm{G}$, doxycycline hydrochloride, and tetracycline. Details of resistances to other antimicrobials were provided in Table 1.

All broiler meat isolates were found multi resistant from 4 to 13 out of 15 antimicrobials tested. The highest MDR rate (35.94\%) belonged to the 4 MDR group, with a sole pattern as $\mathrm{B} / \mathrm{DA} / \mathrm{E} / \mathrm{RD}$, which was also the common pattern within all the broiler meat isolates. Resistances to other antimicrobials over this pattern were given in detail in Table 2. The chicken isolates, which all belonged to serogroup $\mathrm{D}$, showed antimicrobial resistance ranging from 8 to 20 drugs tested. The highest MDR rate $(17.72 \%)$ in chicken isolates was observed in both $10 \mathrm{MDR}$ and $17 \mathrm{MDR}$ groups, where 11 out of 14 in $10 \mathrm{MDR}$ showed a main pattern as $\mathrm{N} / \mathrm{B} / \mathrm{CT} / \mathrm{E} / \mathrm{SP} / \mathrm{P} /$ $\mathrm{RD} / \mathrm{DO} / \mathrm{OT} / \mathrm{TE}$, and 9 out of 14 in $17 \mathrm{MDR}$ revealed a pattern as N/CL/KZ/EFT/B/CT/CIP/ENR/E/SP/AMC/ AMP/P/RD/DO/OT/TE (Table 3).

\section{Discussion and Conclusion}

The high (100.0\%) antimicrobial resistance observed in all of the broiler meat isolates to bacitracin, clindamycin, erythromycin and rifampicin is a unique finding, since in current literature there is no study, which had tested these antimicrobials on this type of isolates. Among these antimicrobials, in our country, bacitracin is the only one used as feed supplement and not used for treatment purposes in poultry. Also, erythromycin, 


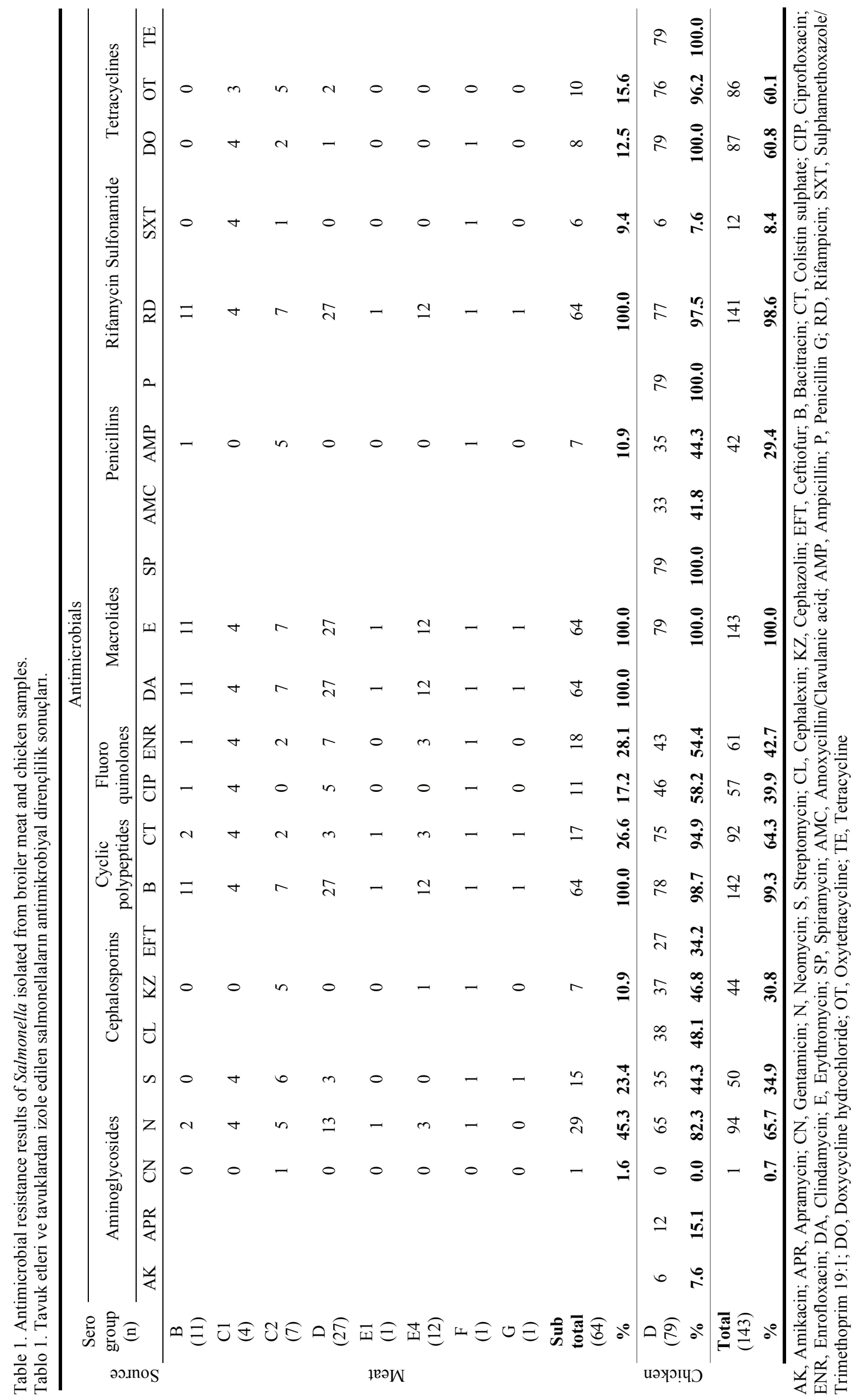




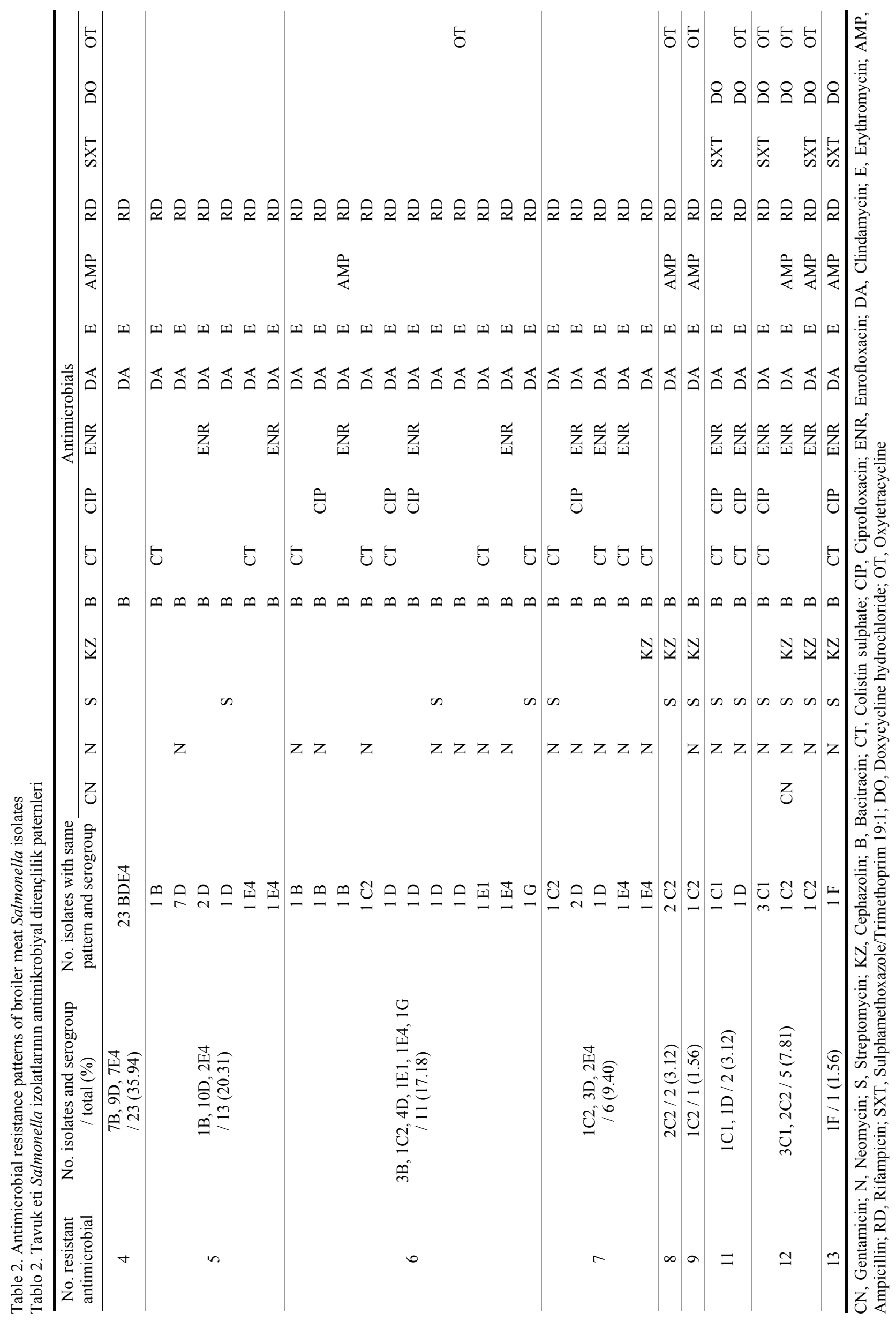




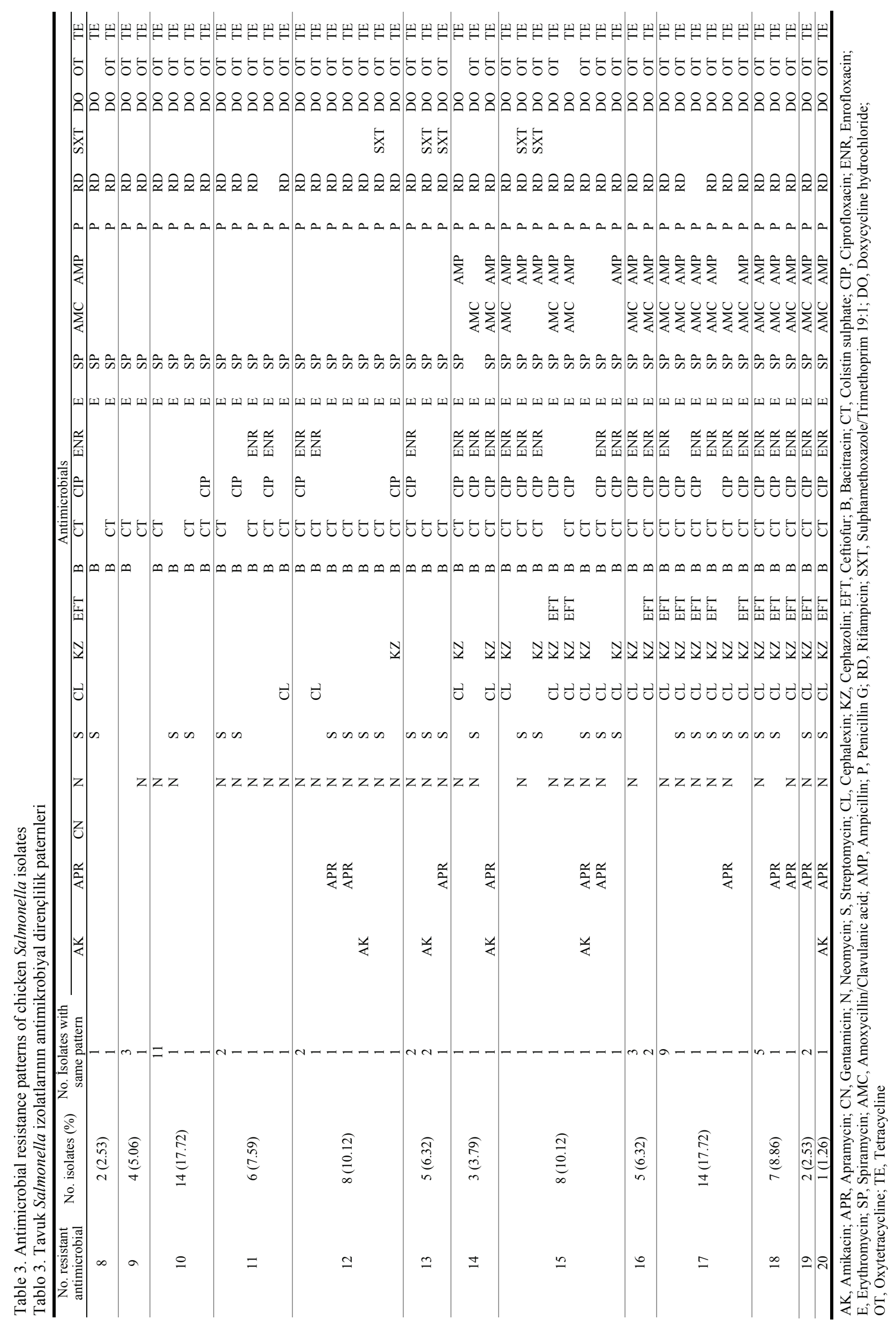


which was being used as supplement and for treatment in poultry between 1980s and 1990s, is not an antimicrobial of current use. The isolates were also checked for resistance status against clindamycin and rifampicin, specific drugs particularly used in human medicine, and it was interesting to find out high resistance against these important antimicriobials in all the isolates tested. The intermediate resistance to neomycin, and relatively lower but notable resistances to enrofloxacin, colistin sulphate, streptomycin, ciprofloxacin, oxytetracycline, doxycycline hydrochloride, ampicillin, and sulphamethoxazole/ trimethoprim 19:1, all of which are the members of drug classes that have widely been used in poultry medicine and/or production for years were remarkable. Our results are in parallel to the previous studies reporting resistance to these antimicrobials, namely for streptomycin and ampicillin $(15,17,18,21,22,23)$, enrofloxacin $(4,21)$, ciprofloxacin and sulphamethoxazole/trimethoprim 19:1 $(4,17,22,23)$. Also, resistance results to doxycycline hydrochloride and oxytetracycline were similar to the previously reported tetracycline resistance results of others $(13,15,17,21,22,23)$.

The high resistance of our serogroup $\mathrm{C} 1$ meat isolates particularly to streptomycin, ciprofloxacin, sulphamethoxazole/trimethoprim 19:1 were similar to the findings of Little et al. (16). For the serogroup C2 isolates' resistances, two studies from the USA showed similarity to our results as: by Lestari et al. (15), who found high resistance to ampicillin, oxytetracycline and streptomycin, and by Parveen et al. (18), who reported high resistance to cephazolin, ampicillin and oxytetracycline in their meat isolates of serovars belonging to serogroup C2. Also, another study from Algeria reported high resistance to tetracycline and streptomycin in their meat isolates belonging to serovar C2 (7). These results indicate that presence of these types of isolates in meat causing human infections would definitely pose risk in treatments, since they show resistance to several important groups of antimicrobials.

The high antimicrobial resistance of the chicken isolates to bacitracin, erythromycin and rifampicin in this study is similar to the findings obtained for the broiler meat isolates. Previously, high resistance to erythromycin in broiler Salmonella isolates was reported by Bekele and Ashenafi (3), who similarly had detected high resistance results for penicillin $\mathrm{G}$, doxycycline hydrochloride in parallel to our findings. Also, the resistance rates determined in this study for the chicken isolates were in agreement with previous reports for tetracycline $(5,12)$, oxytetracycline (10), ciprofloxacin and enrofloxacin (5), enrofloxacin and penicillin $G$ (14), cephalexin and cephazolin (3), streptomycin and ampicillin (3, 5, 12), amoxycillin/clavulanic acid (3), and ceftiofur (10). The resistance rate observed in the broiler isolates for sulphamethoxazole/trimethoprim 19:1 was relatively lower than previously reported by Ishihara et al. (10) in chicken isolates.

Among recent reports of antimicrobial resistance in Salmonella isolated from chicken meat and chickens, the results vary widely among antimicrobials tested and according to the origin of the isolates. When our isolates' resistance results are compared based on the common antimicrobials used in these studies, relatively lower resistance rates to streptomycin $(3,15,17,18,23)$, sulphamethoxazole/trimethoprim 19:1 (4, 10, 17, 22, 23) and to oxytetracycline (10) were found in our study to those previously reported.

The resistance rates obtained in this study were higher than earlier reports of Miranda et al. (17) and Zewdu and Cornelius (23) for ciprofloxacin; of Capita et al. (4) and Van et al. (21) for enrofloxacin; of Ishihara et al. (10), Kang et al. (12), Kasimoglu et al. (13), Lestari et al. (15) and Yan et al. (22) for cephazolin; and of Bekele and Ashenafi (3) for doxycycline hydochloride. There were almost equivalent number of studies reporting higher $(17,18,22,23)$ and lower $(10,15,16,21)$ resistances compared to our ampicillin resistance rates.

The resistance of the Salmonella isolates in this study was substantially higher for the antimicrobials, which are in use for human and veterinary medicine for longer time, with the exceptions of the following drugs previously reported with lower resistance similar to ours: ampicillin $(10,14,15,16,21)$, sulphamethoxazole/ trimethoprim 19:1 $(12,15)$, and gentamicin $(11,14)$. The reasons behind these relatively lower resistances in our Salmonella isolates for these 3 antimicrobials, which also have been used in the treatment of various poultry diseases for a long time need to be investigated in further studies.

Overall evaluation of the resistance rates of broiler meat and chicken isolates indicated prominent resistance to erythromycin, bacitracin, and rifampicin, the latter two antimicrobials with restricted use in large animal practice (20). Also, results of 11 common antimicrobials tested for these isolates showed that resistance rates of the chicken isolates were almost always higher than those of broiler meat isolates except for sulphamethoxazole/ trimethoprim 19:1. All these results imply that the isolates showed resistance to one or more antimicrobial tested, except to gentamicin, to which all but one isolates were found susceptible. This very low overall resistance to gentamicin (with $100 \%$ susceptibility in all chicken Salmonella isolates) shows similarity to previous data by Kalender and Muz (11), and Kilinc and Aydin (14).

The significantly high antimicrobial resistance rates in our Salmonella isolates were probably an indication of their intense use in practice without paying required attention to the following issues: (I) indiscriminate use of antimicrobials with improper administration periods and 
doses (8) both in poultry and human medicine (II) selfmedication by easy access to antimicrobials without prescription (1) in human medicine, (III) use of subtherapeutic dose of antimicrobials for prophylactic/ nutritional purposes in poultry sector; (IV) unintended violations in withdrawal periods of antimicrobials in poultry production. All these practices can cause emergence and dissemination of resistant Salmonella in humans, livestock and their products, such as chicken meat (19).

Another very striking outcome of our study is that all of our broiler meat and chicken Salmonella isolates were MDR to $4-13$ out of 15 , and $8-20$ out of 22 antimicrobials tested, respectively. The $100 \%$ MDR to a minimum of 4 antimicrobials that was detected in our study for the broiler meat isolates surpasses the MDR rates reported in similar recent studies as follows: MDR to $\geq 1: 62.1 \%$ (23), $88.9 \%$ (21); MDR to $\geq 2: 27.8 \%$ (21), 40\% (4), 52.4\% (15), 68.75\% (13), 72.5\% (18), 89.6\% (22); MDR to $\geq 3: 35.7 \%$ (15), 53.4\% (18). Within these studies, several had results with MDR Salmonella isolates with $\geq 4$ antimicrobials still with lower rates compared to ours as: $6.25 \%$ (13), $52.7 \%$ (22), $85.4 \%$ (17), and some indicated resistance in some of their isolates up to 10 antimicrobials $(15,23)$, which is similar to our up to 13 MDR finding. MDR results of our chicken Salmonella isolates showed that our 100\% MDR rate (minimum to 8 antimicrobials) was higher than previous reports of Elgroud et al. (7) and Ishihara et al. (10) (MDR to $\geq 2$ antimicrobials: $51.7 \%$ and $91.3 \%$, respectively), and of Bekele and Ashenafi (3) (MDR to $\geq 3$ antimicrobials: $24.6 \%$ ), who also reported resistance up to 6 antimicrobials in their broiler Salmonella isolates, in contrast to our results.

The MDR pattern common to all meat isolates as $\mathrm{B} / \mathrm{DA} / \mathrm{E} / \mathrm{RD}$, and the main pattern of $\mathrm{N} / \mathrm{B} / \mathrm{CT} / \mathrm{E} / \mathrm{SP} / \mathrm{P} /$ $\mathrm{RD} / \mathrm{DO} / \mathrm{OT} / \mathrm{TE}$ in most of the chicken isolates showed no one to one similarity/commonality to the previous reports on chicken meat $(13,15,17,18,23)$ and chicken $(10,12)$. As one should expect, this could be mainly related to the differences in the specific antimicrobials used in different studies, serovar/serogroup differences of the isolates, country or regional origin of the isolates, and the source or type of the isolate.

In our study, the number of antimicrobials/ antimicrobial families that our broiler meat isolates were MDR to were questioned, and it was observed that serogroup B, D and E4 isolates showed relatively lower MDR (4 to 6 antimicrobials in all B; 4 to 7 antimicrobials in all E4; 4 to 7 antimicrobials in all but one D), than $\mathrm{C} 1$ and $\mathrm{C} 2$ isolates. Additionally, most/all $\mathrm{C} 1$ and/or $\mathrm{C} 2$ serogroup isolates, with relatively higher MDRs (mostly $\geq 7$ antimicrobials), were the dominant serogroups in resistance to streptomycin, cephazoline, ciprofloxacin, enrofloxacin, ampicillin, sulphamethoxazole/trimethoprim
19:1, doxycycline hydrochloride and oxytetracycline. This type of a tendency in the studied serogroups is an interesting note open to further genotype based investigations, due to the absence of serovar information of our isolates, and since one serogroup is comprised of many serovars, which can definitely exhibit different antimicrobial resistance phenotypes, and even under a specific serovar, number of resistant antimicrobials can vary in great extent for different isolates as seen in previous reports $(13,21)$. Also, in the broiler meat versus chicken isolate comparisons, limited to antimicrobials tested in both groups of isolates, revealed that there were substantially more chicken isolates $(92.4 \%)$ than broiler meat isolates $(25.0 \%)$ showing MDR with resistance to $\geq$ 7 antimicrobials (data not shown in detail). At this point, this finding should be left as entirely coincidental, since it is restricted to observations in these isolates.

The considerably high resistance rates and MDR types to commonly used antimicrobial agents among the Salmonella isolates tested in our study once more indicated strict implementation of pertinent regulations in conjunction with reliable control systems, to establish prudent use of these antimicrobials in veterinary and human medicine.

\section{References}

1. Acha PN, Szyfres B (2001): Zoonoses and Communicable Diseases Common to Man and Animals. 3rd edn., Washington DC: Pan American Health Organization,Vol.1, pp. 233-246.

2. Angulo FJ, Nargund VN, Chiller TC (2004): Evidence of an association between use of anti-microbial agents in food animals and anti-microbial resistance among bacteria isolated from humans and the human health consequences of such resistance. J Vet Med B, 51, 374379.

3. Bekele B, Ashenafi M (2010): Distribution of drug resistance among enterococci and Salmonella from poultry and cattle in Ethiopia. Trop Anim Health Pro, 42, 857864.

4. Capita R, Alonso-Calleja C, Prieto M (2007): Prevalence of Salmonella enterica serovars and genovars from chicken carcasses in slaughterhouses in Spain. J Appl Microbiol, 103, 1366-1375.

5. Chiu LH, Chiu CH, Horn YM, Chiou CS, Lee CY, Yeh CM, Yu CY, Wu CP, Chang CC, Chu C (2010): Characterization of 13 multi-drug resistant Salmonella serovars from different broiler chickens associated with those of human isolates. BMC Microbiol, 10, 86.

6. Clinical and Laboratory Standards Institute (CLSI) (2006): Performance Standards for Antimicrobial Disk Susceptibility Tests. Approved Standard, $10^{\text {th }}$ edn. Documents M02-A10, M7-A8, M100-S19, Vol. 26, No. 1. Pennsylvania, PA, USA.

7. Elgroud R, Zerdoumi F, Benazzouz M, BouzitounaBentchouala C, Granier SA, Frémy S, Brisabois A, Dufour B, Millemann Y (2009): Characteristics of Salmonella contamination of broilers and slaughterhouses 
in the region of Constantine (Algeria). Zoonoses Public Hlth, 56, 84-93.

8. Guthrie RK (1992): Salmonella, CRC Press, USA, pp. 23156.

9. Hohmann EL (2001): Nontyphoidal salmonellosis. Clin Infect Dis, 32, 263-269.

10. Ishihara K, Takahashi T, Morioka A, Kojima A, Kijima M, Asai T, Tamura Y (2009): National surveillance of Salmonella enterica in food-producing animals in Japan. Acta Vet Scand, 51, 35.

11. Kalender H, Muz A (1999): Typing of Salmonella speciess isolated from chickens in Elazıg region. Turk J Vet Anim Sci, 23, 297-303.

12. Kang ZW, Jung JH, Kim SH, Lee BK, Lee DY, Kim YJ, Lee JY, Won HK, Kim EH, Hahn TW (2009): Genotypic and phenotypic diversity of Salmonella Enteritidis isolated from chickens and humans in Korea. $\boldsymbol{J}$ Vet Med Sci, 71, 1433-1438.

13. Kasimoglu Dogru A, Ayaz ND, Gencay YE (2009): Serotype identification and antimicrobial resistance profiles of Salmonella spp. isolated from chicken carcasses. Trop Anim Health Pro, 42, 893-897.

14. Kilinc U, Aydin F (2006): Antibiotic susceptibility of Salmonella spp. isolated chicken from poultry enterprises in Kayseri region. J Health Sci, 15, 35-40.

15. Lestari SI, Han F, Wang F, Ge B (2009): Prevalence and antimicrobial resistance of Salmonella serovars in conventional and organic chickens from Louisiana retail stores. J Food Prot, 72, 1165-1172.

16. Little CL, Richardson JF, Owen RJ, De Pinna E, Threlfall EJ (2008): Prevalence, characterisation and antimicrobial resistance of Campylobacter and Salmonella in raw poultry meat in the UK, 2003-2005. Int J Environ Heal R, 18, 403-414.

17. Miranda JM, Mondragon AC, Martinez B, Guarddon M, Rodriguez JA (2009): Prevalence and antimicrobial resistance patterns of Salmonella from different raw foods in Mexico. J Food Prot, 72, 966-971.
18. Parveen S, Taabodi M, Schwarz JG, Oscar TP, HarterDennis J, White DG (2007): Prevalence and antimicrobial resistance of Salmonella recovered from processed poultry. J Food Prot, 70, 2466-2472.

19. Poppe C (1999): Epidemiology of Salmonella enterica serovar Enteritidis, In: A.M. Saeed, R.K. Gast, P.G. Wall (eds), Salmonella enterica serovar Enteritidis in Humans and Animals: Epidemiology, Pathogenesis and Control, Iowa State Univ. Press, USA, pp. 3-18.

20. Turkish Food Codex (2002): Regulation on the maximum residue limits on veterinary drugs in animal-derived foods. Legislation No: 2002/30.

21. Van TTH, Moutafis G, Istivan T, Tran LT, Coloe PJ (2007): Detection of Salmonella spp. in retail raw food samples from Vietnam and characterization of their antibiotic resistance. Appl Environ Microb, 73, 68856890.

22. Yan H, Li L, Alam MJ, Shinoda S, Miyoshi S, Shi L (2010): Prevalence and antimicrobial resistance of Salmonella in retail foods in Northern China. Int J Food Microbiol, 143, 230-234.

23. Zewdu E, Cornelius P (2009): Antimicrobial resistance pattern of Salmonella serotypes isolated from food items and personnel in Addis Ababa, Ethiopia. Trop Anim Health Pro, 41, 241-249.

Geliş tarihi: 07.09.2011 / Kabul tarihi: 17.11.2011

Address for correspondence:

Prof. Dr. Aysegul Eyigor

Department of Food Hygiene and Technology

Faculty of Veterinary Medicine

Uludag University 16059, Görükle Campus

Bursa, Turkey

Email: aeyigor@uludag.edu.tr

Phone: +90.224.2941334

Fax: +90.224.294 1202 